\title{
Effects of Cowdung and Poultry Manure on Growth Performance of Indian Major Carps (Catla catla, Labeo rohita) and Exotic Carp (Cyprinus carpio) in Thatta District (Sindh), Pakistan
}

\author{
Mohammad Shoaib ${ }^{\mathrm{a} *}$, Syed Anser Rizvi ${ }^{\mathrm{a}}$, Faisal Ameer ${ }^{\mathrm{b}}$ and Mohammad Nasir ${ }^{\mathrm{b}}$ \\ ${ }^{a}$ Department of Zoology, University of Karachi, Karachi - 75270, Pakistan \\ ${ }^{b}$ FMRRC, PCSIR Laboratories Complex, Shahrah-e-Dr. Salimuzzaman Siddiqui, Karachi - 75280, Pakistan
}

(received April 20, 2010; revised August 24, 2010; accepted September 24, 2010)

\begin{abstract}
In the manuring trials conducted in earthen ponds of $120 \mathrm{~m}^{2}$ for one year, the juveniles of Indian major carps (Catla catla and Labeo rohita) and exotic carp (Cyprinus carpio) responded positively during warmer months i.e. March to August. The mean weight increase and mean specific growth rate (SGR) were better in the ponds fertilised with cowdung. Total growth rate per day calculated for Catla catla was $32.96 \mathrm{~g}$, for Labeo rohita $95.02 \mathrm{~g}$ and for Cyprinus carpio $14.37 \mathrm{~g}$ under the influence of cowdung. Moreover individual growth rates/day were also high i.e. 2.06, 2.50 and 1.43 g, respectively. Percent contribution in fish production was $23.15 \%$., $66.74 \%$ and $10.09 \%$, respectively. Total growth rate of the three was significantly higher in cowdung (142.36 g) as compared to that in poultry manure i.e. $106.64 \mathrm{~g}$. Both the fertilisers significantly differed in terms of monthly and treatment variations $(\mathrm{P}<0.05)$ except for treatment variation for Cyprinus carpio. Water temperature, light penetration, electrical conductivity, total dissolved solids, total suspended solids and nitrates were highly significant $(\mathrm{P}<0.05)$ both for treatment and monthly variation except $\mathrm{pH}$ and dissolved oxygen.
\end{abstract}

Keywords: poly-culture, carp farming, organic manure, Catla catla, Labeo rohita, Cyprinus carpio

\section{Introduction}

Use of animal wastes like poultry manure and cowdung has been practiced for long for generation of algal blooms which play a vital role in developing ecofriendly, economical and socially viable cultural system. According to Dhawan and Kaur (2002), cowdung and poultry manure proved to be the best organic fertilisers when used adequately.

Conversely, indiscriminate use of these fertilisers in fish ponds, instead of improving the primary productivity, may also lead to pollution. Therefore, developing standards for doses is necessary which would control the ecological parameters of pond water for favourable growth of fish like major and common carps (BARC, 1997). The cowdung and poultry manure, when recycled, produce soluble phosphorous, nitrogen and carbon for algal growth and natural food production (Knud-Hansen et al., 1991).

Work has been on record on the utilization of cowdung and poultry manure for growth of conventional Indian major carps. The present study was conducted to work out the effects of these manures on (i) growth performance, (ii) production of planktonic biomass and

*Author for correspondence; E-mail: drmshoaib_11273@yahoo.com (iii) physicochemical parameters of fish pond of carps (Indian major and exotic carps) in poly-culture system.

Conventionally, three species of Indian major carps namely Catla catla (suface feeder), Labeo rohita (column feeder) and Cirrhina mrigala (bottom feeder) were stocked in a fish pond (Javed et al., 1992). Presently instead of C. mrigala, Cyprinus carpio has been stocked as bottom feeder considering the findings of Milstein et al. (2002).

\section{Materials and Methods}

Experiments were conducted in three replications for both manuring trials in earthen ponds (size $\sim 120 \mathrm{~m}^{2}$, water depth $1.5 \mathrm{~m}$ ) in Thatta district (Sindh), Pakistan. The experimental neonates of Indian major carp and exotic carp were obtained by means of induced breeding technique. The ponds were stocked with stocking density of 16:38:10 (Catla catla: Labeo rohita: Cyprinus carpio) according to Sheri et al. (1986).

Pond preparation. The existing fish ponds were emptied and sun dried. To avoid any infection, liming was done after fifteen days interval. The inlets and 
outlets of all ponds were sealed with fine mesh gauze for blocking the intrusion of any predator into the pond or the exit of experimental fish from the pond.

Manuring of fish ponds. Nitrogen content of the test manures was estimated by means of Kjeldahl method following the analytical procedure of AOAC (1990). The amount of manure used in the ponds was calculated on the basis of nitrogen availability. Poultry manure at the rate of $0.17 \mathrm{~g} \mathrm{~N} / 100 \mathrm{~g}$ and cowdung at the rate of $0.2 \mathrm{~g} \mathrm{~N} / 100 \mathrm{~g}$ of stocked fish were introduced daily.

Parameters studied. During the study, following parameters were recorded:

1. Monthly increase in weight $=$ Final mean weight (g) - Initial mean weight (g)

2. Specific growth rate

$$
(\% / \text { day })=\frac{\log W_{t_{t}}-\log W_{t_{i}}}{\text { Time }} \times 100
$$

3. Individual performance of experimental Indian major carps and common carp.

4. Physical parameters of pond water included temperature, light penetration, $\mathrm{pH}$, electrical conductivity, total dissolved solids (TDS) and total suspended solids (TSS).

5. Chemical parameters included nitrate nitrogen, dissolved oxygen and total hardness of water. Prior to chemical analysis, water samples were collected and brought in the laboratory. For dissolved oxygen, water samples were fixed immediately after sampling as described by Welch (1952). Nitrate nitrogen and total hardness were determined by Merck chemical test kits for testing water and wastewaters.

Statistical analysis. The obtained data were subjected to statistical analysis using MINITAB Release 14. Mean values for various parameters and significance levels were determined using two way analysis of variance (ANOVA).

\section{Results and Discussion}

Growth of fish. When fertilised with poultry manure, Catla catla mean weight (g) was observed to lower considerably during the four months of November to February (16.44, 13.12, 12.64 and $14.78 \mathrm{~g}$ ) because of lowering of water temperature (Table 1 ). It started to improve after winter; from March to August, mean weight increased upto $112.9 \mathrm{~g}$. While in cowdung treated ponds the mean weight of $C$. catla started to increase right from the beginning (16.47 $\mathrm{g}$ in September) and continued upto $92.93 \mathrm{~g}$ in July but lowered slightly in the last month of experiment (August, 86.80 g) (Table 1). Better specific growth rate (SGR) was noted during the whole experimental periods.

Table 1. Growth performance of Catla catla under the influence of poultry manure and cowdung

\begin{tabular}{lllllllll}
\hline \hline \multirow{2}{*}{ Months } & \multicolumn{3}{c}{ Poultry manure } & & \multicolumn{3}{c}{ Cowdung } \\
\cline { 2 - 3 } \cline { 7 - 8 } & Mean & \multicolumn{2}{c}{ Mean wt. } & Mean & & Mean & Mean wt. & Mean \\
& weight & increase & SGR & & weight & increase & SGR \\
\hline September & 78.15 & 58.92 & 0.813 & & 68.53 & 16.47 & 0.306 \\
October & 137.32 & 59.0 & 0.323 & & 85.00 & 22.57 & 0.336 \\
November & 172.27 & 16.44 & 0.126 & & 107.57 & 30.97 & 0.360 \\
December & 188.7 & 13.12 & 0.093 & & 138.5 & 48.0 & 0.416 \\
January & 201.83 & 12.64 & 0.083 & & 186.5 & 68.1 & 0.400 \\
February & 214.47 & 14.78 & 0.093 & & 247.6 & 67.43 & 0.343 \\
March & 229.3 & 39.63 & 0.226 & & 315.0 & 82.33 & 0.340 \\
April & 269.2 & 49.68 & 0.240 & & 397.3 & 84.93 & 0.276 \\
May & 318.8 & 55.5 & 0.223 & & 482.3 & 87.83 & 0.240 \\
June & 374.3 & 67.5 & 0.223 & & 570.1 & 88.90 & 0.210 \\
July & 441.9 & 84.7 & 0.236 & & 659.0 & 92.93 & 0.186 \\
August & 526.5 & 112.9 & 0.336 & & 751.9 & 86.80 & 0.153 \\
\hline \hline
\end{tabular}

Table 2 exhibits growth performance of Labeo rohita in ponds receiving poultry manure and cowdung. $L$. rohita responded similar to C. catla in poultry manured ponds i.e. the attainment of weight was observed during warmer months up to $130.79 \mathrm{~g}$ in August. In cowdung treated ponds, the weight gain increased in the beginning and continuously showed addition upto August (95.13 g). With respect to

Table 2. Growth performance of Labeo rohita under enrichment of the poultry manure and cowdung

\begin{tabular}{lllllllll}
\hline \hline \multirow{2}{*}{ Months } & \multicolumn{3}{c}{ Poultry manure } & & \multicolumn{3}{c}{ Cowdung } \\
\cline { 2 - 3 } \cline { 7 - 8 } & Mean & \multicolumn{2}{c}{ Mean wt. } & Mean & & Mean & \multicolumn{3}{c}{ Mean wt. Mean } \\
& weight & increase & SGR & & weight & increase & SGR \\
\hline September & 58.77 & 47.49 & 0.847 & 88.27 & 19.66 & 0.283 \\
October & 106.25 & 41.07 & 0.463 & & 107.93 & 32.06 & 0.373 \\
November & 147.3 & 39.47 & 0.333 & & 140.00 & 42.03 & 0.376 \\
December & 186.8 & 14.24 & 0.100 & & 181.97 & 70.90 & 0.470 \\
January & 201.0 & 10.36 & 0.066 & & 252.87 & 90.10 & 0.436 \\
February & 211.4 & 23.31 & 0.150 & & 342.97 & 93.96 & 0.346 \\
March & 234.7 & 39.29 & 0.220 & & 437.00 & 93.06 & 0.276 \\
April & 274.0 & 58.14 & 0.283 & 530.07 & 94.33 & 0.233 \\
May & 332.1 & 76.3 & 0.296 & & 624.40 & 95.93 & 0.203 \\
June & 408.5 & 114.4 & 0.343 & & 720.33 & 97.00 & 0.176 \\
July & 522.9 & 130.4 & 0.313 & 817.33 & 95.40 & 0.153 \\
August & 653.2 & 130.7 & 0.253 & & 912.73 & 95.13 & 0.136 \\
\hline \hline
\end{tabular}


growth per day it was noticed that SGR was healthy $(0.305 \% /$ day $)$ with poultry manure treatment as compared to $0.288 \% /$ day in the case of cowdung.

Approximately same size of juvenile Cyprinus carpio were stocked in poultry manure and cowdung treated ponds. The minimum weight increase was recorded during December to March (12.129 g in January), the winter months, while weight increased by $100.8 \mathrm{~g}$ (maximum) in July when ponds were enriched with poultry manure. C. carpio did not show good response earlier in cowdung enriched ponds as generally they prefer food items in bottom soil; the organic materials sometimes took about two months to settle in the bottom soil or pond embarkment. Later on, their weight increased gradually in the range of $33.70 \mathrm{~g}$ in January upto $57.10 \mathrm{~g}$ in August. SGR followed, the trend of L. rohita, being $0.243 \%$ /day with poultry manure treatment and $0.203 \%$ /day with cowdung treatment (Table 3).

Table 3. Growth performance of Cyprinus carpio under enrichment of the poultry manure and cowdung

\begin{tabular}{llllllll}
\hline \hline \multirow{2}{*}{ Months } & \multicolumn{3}{c}{ Poultry manure } & & \multicolumn{3}{c}{ Cowdung } \\
\cline { 2 - 4 } \cline { 7 - 8 } & $\begin{array}{l}\text { Mean } \\
\text { weight }\end{array}$ & $\begin{array}{l}\text { Mean wt. } \\
\text { increase }\end{array}$ & SGR & & $\begin{array}{l}\text { Mean } \\
\text { weight }\end{array}$ & $\begin{array}{l}\text { Mean wt. } \\
\text { increase }\end{array}$ & SGR \\
\hline September & 84.25 & 35.05 & 0.496 & 88.20 & 23.00 & 0.326 \\
October & 119.3 & 41.08 & 0.433 & & 111.20 & 25.93 & 0.296 \\
November & 161.53 & 35.52 & 0.296 & 137.20 & 39.07 & 0.290 \\
December & 198.80 & 22.6 & 0.076 & 168.00 & 34.87 & 0.290 \\
January & 209.75 & 12.12 & 0.076 & 206.20 & 33.70 & 0.216 \\
February & 221.84 & 13.54 & 0.086 & 239.90 & 44.20 & 0.236 \\
March & 236.8 & 22.13 & 0.166 & 284.1 & 42.77 & 0.196 \\
April & 267.5 & 37.67 & 0.213 & 326.9 & 45.40 & 0.180 \\
May & 311.9 & 58.19 & 0.283 & & 372.3 & 47.50 & 0.170 \\
June & 381.0 & 77.80 & 0.306 & & 419.8 & 50.57 & 0.156 \\
July & 472.4 & 100.8 & 0.246 & & 470.3 & 54.53 & 0.153 \\
August & 567.9 & 62.3 & 0.243 & 524.8 & 57.10 & 0.146 \\
\hline \hline
\end{tabular}

Individual performance. In cowdung treated ponds, the growth rate per day of $C$. catla was $32.96 \mathrm{~g}$, of L. rohita, $95.02 \mathrm{~g}$ and that of C. carpio, $14.37 \mathrm{~g}$. Individual growth rate per day was 2.06, 2.50 and $1.43 \mathrm{~g}$, respectively. Percent contribution of these experimental fishes was recorded as $23.15 \%, 66.74 \%$ and $10.09 \%$. Total growth rate at the harvest of all the three species was $142.36 \mathrm{~g}$ per day (Table 4).

The growth rates per day of C. catla $23.07 \mathrm{~g}$, L. rohita $68.00 \mathrm{~g}$ and C. carpio $15.55 \mathrm{~g}$ were recorded in poultry manure treated ponds. The individual growth
Table 4. Individual performance and percent contribution of experimental fishes under enrichment of the poultry manure and cowdung

\begin{tabular}{|c|c|c|c|}
\hline Fishes & $\begin{array}{l}\text { Growth } \\
\text { rate/day }\end{array}$ & $\begin{array}{l}\text { Individual growth } \\
\text { rate/day }\end{array}$ & $\begin{array}{l}\text { Contribution } \\
\text { (\%) }\end{array}$ \\
\hline Catla catla & 23.07 & 1.44 & 21.64 \\
\hline Labeo rohita & 68.00 & 1.78 & 63.76 \\
\hline Cyprinus carpio & 15.55 & 1.55 & 14.58 \\
\hline \multicolumn{4}{|c|}{ Total growth rate of three species in poultry manure $106.64 \mathrm{~g} /$ day } \\
\hline Catla catla & 32.96 & 2.06 & 23.15 \\
\hline Labeo rohita & 95.02 & 2.50 & 66.74 \\
\hline Cyprinus carpio & 14.37 & 1.43 & 10.09 \\
\hline
\end{tabular}

rate per day of C. catla was $1.44 \mathrm{~g}$, of L. rohita $1.78 \mathrm{~g}$ and that of C. carpio $1.55 \mathrm{~g}$. Total growth rate at the time of harvest was recorded to be $106.64 \mathrm{~g} /$ day. Percent contribution of all fishes was recorded as $21.64 \%, 63.76 \%$ and $14.58 \%$ (Table 4). Statistically it was also noticed that $C$. catla mean weight significantly differed $(\mathrm{P}<0.05)$ both in case of the treatment and the monthly variations (Table 5).

Table 5. Analysis of variance (GLM) of experimental fishes for monthly and treatment variations

\begin{tabular}{llllll}
\hline \hline \multirow{2}{*}{ Fishes } & \multicolumn{2}{c}{ Months } & & \multicolumn{2}{c}{ Treatments } \\
\cline { 2 - 3 } \cline { 5 - 6 } & F-value & P-value & & F-value & P-value \\
\hline Catla catla & 27.34 & $0.000^{*}$ & & 12.82 & $0.000^{*}$ \\
Labeo rohita & 12.33 & $0.000^{*}$ & & 16.09 & $0.002^{* *}$ \\
Cyprinus carpio & 66.04 & $0.000^{*}$ & & 0.90 & $0.362 *$ \\
\hline \hline & & & & & \\
\hline
\end{tabular}

Physicochemical parameters of water. Poultry manure and cowdung were introduced to supply adequate levels of nutrients necessary for production of primary products and ultimately for the fish. During this process, the physicochemical parameters of water considerably fluctuated affecting the growth rate of experimental fish. Tables 6 and 7 show mean annual values along with their values for analysis of variance (F-values and P-values) for both the treatments and the monthly variations. Significant differences $(\mathrm{P}<0.05)$ were observed in light penetration, electrical conductivity, nitrates, total dissolved solids and total suspended solids of both the treatment and the monthly variations. However, non-significand difference was noticed only in temperature in case of treatment variation while the monthly variation remained significantly different. 
Table 6. Physicochemical parameters of water enriched with poultry manure and cowdung

\begin{tabular}{|c|c|c|c|c|c|c|}
\hline \multirow[t]{2}{*}{ Variables } & \multicolumn{3}{|c|}{ Poultry manure } & \multicolumn{3}{|c|}{ Cowdung } \\
\hline & $\overline{M e a n} \pm S E$ & Min & Max & Mean \pm SE & Min & Max \\
\hline Temperature $\left({ }^{\circ} \mathrm{C}\right)$ & $21.65 \pm 2.16$ & 11.98 & 31.15 & $22.18 \pm 2.07$ & 12.52 & 30.85 \\
\hline Light penetration (cm) & $12.55 \pm 1.34$ & 7.93 & 23.59 & $18.492 \pm 0.856$ & 14.800 & 22.700 \\
\hline $\mathrm{pH}$ & $8.017 \pm 0.101$ & 7.40 & 8.70 & $8.5325 \pm 0.0580$ & 8.250 & 8.950 \\
\hline $\begin{array}{l}\text { Electrical conductivity } \\
\text { (m.mhos.cm) }\end{array}$ & $1.904 \pm 0.0423$ & 1.700 & 2.09 & $1.780 \pm 0.0193$ & 1.660 & 1.870 \\
\hline Total dissolved solids (mg/L) & $266.47 \pm 6.59$ & 222.33 & 308.66 & $244.8 \pm 22.3$ & 150.0 & 370.0 \\
\hline Total solids (mg/L) & $1689 \pm 102$ & 1186 & 2238 & $1946 \pm 130$ & 450 & 1203 \\
\hline Dissolved oxygen (mg/L) & $5.741 \pm 0.584$ & 2.90 & 9.93 & $13.225 \pm 0.219$ & 11.80 & 14.30 \\
\hline Nitrates (mg/L) & $2.785 \pm 0.379$ & 0.220 & 5.220 & $5.252 \pm 0.0665$ & 4.880 & 5.650 \\
\hline Total hardness (mg/L) & $266.47 \pm 6.59$ & 222.33 & 308.66 & $244.8 \pm 22.3$ & 150.0 & 370.0 \\
\hline
\end{tabular}

$\mathrm{pH}$, dissolved oxygen and total hardness also differed non-significantly only for monthly variation and was highly significant for poultry manure and cowdung (Table 7).

Indian major carps, including Catla catla (surface feeder) and Labeo rohita (column feeder) along with Cyprinus carpio (bottom feeder) were stocked to evaluate the response of pond enrichment. These fishes are excellent respondent to different pond niches. The present study revealed that these fishes fully utilized the available food, generated by pond enrichment. During the study, the stocking of C.carpio with C. catla and $L$. rohita produced positive environmental results because the C.carpio damaged the embarkment without creating any harmful effect on the rest of two fishes. Besides this, the nutrients released by the soil were evenly dispersed in the experimental ponds to promote the planktonic biomass. The present results regarding the stocking of major carps and common carp also conform to those of Wahab et al. (2002) who found that the feeding habit of common carp was certainly helpful for nutrient mixing from soil compared to conventional bottom feeder fish. There were no effects on the performance of C. catla and L. rohita. Considering present results of manuring trials, the best growth (142.36 g/day) was observed with the use of cowdung (Table 5) followed by the poultry manure (106.64 g/day) which concluded that cowdung has an edge over poultry manure (organic fertiliser). Rappaport and Sarig (1978) claimed that the cowdung feed for fish culture produced highly positive results as compared to that of the poultry droppings, which confirm present findings. Machaodo and Costagnolli
Table 7. Analysis of variance for various physicochemical parameters of water enriched with different fertilizers

\begin{tabular}{llllll}
\hline \hline \multirow{2}{*}{ Variables } & \multicolumn{2}{c}{ Treatment } & & \multicolumn{2}{c}{ Months } \\
\cline { 2 - 3 } \cline { 5 - 6 } \cline { 5 - 6 } & F-values & P-values & & F-values & P-values \\
\hline Temperature $\left({ }^{\circ} \mathrm{C}\right)$ & 2.72 & 0.060 & & 211.89 & $0.000^{* *}$ \\
Light penetration $(\mathrm{cm})$ & 36.46 & 0.000 & & 4.36 & $0.000^{* *}$ \\
$\mathrm{pH}$ & 10.97 & 0.000 & & 1.33 & $0.254^{*}$ \\
$\begin{array}{l}\text { Electrical conductivity } \\
\text { (m.mhos.cm) }\end{array}$ & 70.11 & 0.000 & & 18.14 & $0.000^{* *}$ \\
$\begin{array}{l}\text { Total dissolved solids } \\
\text { (mg/L) }\end{array}$ & 38.82 & 0.000 & & 2.41 & $0.025^{* *}$ \\
Total solids (mg/L) & 31.43 & 0.000 & & 2.95 & $0.008^{* *}$ \\
$\begin{array}{l}\text { Dissolved oxygen } \\
\text { (mg/L) }\end{array}$ & 89.87 & 0.000 & & 1.48 & $0.188^{*}$ \\
Nitrates (mg/L) & 49.26 & 0.000 & & 2.34 & $0.029^{* *}$ \\
Total hardness (mg/L) & 8.34 & 0.000 & & 1.90 & $0.075^{*}$ \\
\hline \hline
\end{tabular}

** = significant; $*$ = non significant.

(1979) also favoured the use of cowdung to rear carp fingerlings instead of inorganic fertilisers. However, Banergee et al. (1979) reported that poultry manure can maximize fish production as it can provide nitrogen adequately for development of phytoplankton and zooplankton which serve as food items for fish. Kang'ombe et al. (2006) suggested that chicken manure treatment produced large amount of chlorophyll along with large number of zooplanktons indicating high levels of primary producers than cattle and pig manure.

As mentioned in Tables 1-3, growth rates of all the experimental fishes were slow due to low feeding rate 
up to the month of February. The available primary producers gradually flourished with the increase in the temperature and thus in the decomposition rate of poultry manure and cowdung.

Goolish and Adelman (1984) found that a unit change in temperature directly affects the growth of fish as the two are proportional to one another. Javed (1988) reported that the stocked fish (major carps) responded significantly when the temperature was between 30.00 to $33.73{ }^{\circ} \mathrm{C}$. Conversely to this, during the present study, major carps showed the best growth within the temperature range of $22.89{ }^{\circ} \mathrm{C}$ to $31.15,26.42$ to $30.85{ }^{\circ} \mathrm{C}, 23.40$ to $30.80{ }^{\circ} \mathrm{C}$ and 27.77 to $30.68{ }^{\circ} \mathrm{C}$ when the pond received poultry manure or the cowdung. The findings of Barthelmes and Bramick (2003) seemed to deviate. They reported silver carp grew better in the temperature range of $18.00{ }^{\circ} \mathrm{C}$ to $22.00{ }^{\circ} \mathrm{C}$.

Individual performance of weight gain of $L$. rohita remained better with cowdung ( $250 \mathrm{~g} /$ day) followed by poultry manure ( $1.78 \mathrm{~g} /$ day). The maximum weight gained by $L$. rohita may be due to its efficiency in conversion of available food (phytoplankton) to flesh (Jhingran and Pullin, 1985). C. catla attained maximum weight gain (2.06 g/day) under the enrichment of cowdung followed by poultry manure (1.44 g/day). The C. carpio, as bottom feeder fish, gained $1.55 \mathrm{~g} /$ day of weight in pond receiving poultry manure while in cowdung treated pond, $1.43 \mathrm{~g}$ /day weight gain was observed (Table 5). The abovementioned results are very much similar to the findings of some other workers including Javed and Sial (1991) who reported that Indian major carp yield of 3360.40 and $3215.60 \mathrm{~kg} / \mathrm{ha} /$ year can be obtained through the use of broiler and layer droppings, respectively, when applied at the rate of $0.10 \mathrm{~g}$ N/100 $\mathrm{g}$ of body weight on daily basis. Natarjan and Varghese (1980) concluded that poultry manure was better fertilizer for maximizing the pond productivity (2728.0 kg/ha/year) than digested sewage sludge (2156.00 kg/ha/year) and cowdung (1811.00 kg/ha/ year). Garg and Bhatnagar (1999) optimized the rate of cowdung for increasing the pond productivity and fish biomass; $4.45 \mathrm{~kg}$ fish biomass and 2.36\% (SGR) weight per day were observed when the $15000 \mathrm{~kg} / \mathrm{ha} /$ year cowdung was applied.

The present findings regarding the effect of temperature on fish yield are in line with the results of Beitinger and Fitzpatrick (1979) who suggested total optimum growth of fish may coincide with the temperature because the latter maximizes the metabolic efficiency of fishes. Jinghran (1982) stated that major carps thrived well in temperature range of $18.3-37.8^{\circ} \mathrm{C}$, while the grass carp, silver carp and common carp preferred temperatures below $30^{\circ} \mathrm{C}$. Annual variations in temperature have a great impact on primary productivity and also speed up the chemical change in water and soil. Singh (1964) reported that temperature and light penetration were the two important factors responsible for regulating the maximum and minimum production of phytoplankton. However, the report of Parveen (1986) contradicts the present findings as the correlation coefficient between the dry weight of planktonic biomass and physical factors like temperature, light penetration, electrical conductivity etc. was nonsiginificant. Brezonic et al. (1984) suggested that high $\mathrm{pH}$ values prompted the growth of phytoplankton and resulted in blooms, while on the contrary, Nazneen (1980) argued that high values of $\mathrm{pH}$ during phytoplankton blooming period were the result of and not the cause of phytoplanktonic blooms. According to Hawkins and Griffith (1986), the pattern of light varies at different times of the year which exclusively depends on the stratification conditions and dominance of phytoplankton species.

Dissolved oxygen contents, when both the fertilizers were used, showed irregularity in variation related to temperature and abundance of phytoplanktons. The results of present experiments were similar to the ones reported by Chiba (1971). Sharma et al. (1979) reported that the concentration of dissolved oxygen depended on both the physical and the biological factors. Depletion of dissolved oxygen was due to respiration of bacteria and phytoplankton and it was compensated by zooplankton and algae during daytime through photosynthesis.

The availability of nitrogen in the form of nitrate was highly noticed during the present study. Nitrates in both the fertilisers significantly differed in months and treatments. It is an important factor in the planktonic biomass production and is accordingly related to the findings of Mahboob and Sheri (1993), who mentioned significant contribution of nitrates towards the growth of fish.

Total hardness was also highly significant during the whole experimental period but non-significant for both 
the types of applied fertilizers. These results are in line with the reports of Vasisht and Jindal (1980) that phytoplankton showed a direct relationship with the light penetration, $\mathrm{pH}$, dissolved oxygen and hardness of water. Parveen (1986) reported that correlation coefficient for nitrates, total hardness and dry weight of planktonic biomass was non-significant.

The present study concluded that for ecological and economical sustainability, optimum dose of fertilisers for fish were evidently necessary for maximum net revenue.

\section{References}

AOAC 1990. Official Methods of Analysis of the $A O A C, 15^{\text {th }}$ edition, Association of Official Analytical Chemists, Arlington, VA, USA.

Banergee, R.K., Ray, P., Singil, G.S., Dutta, B.R. 1979. Poultry droppings- its manurial potentiality in aquaculture. Journal of the Inland Fisheries Society of India, 2: 94-108.

BARC 1997. Fertilizer Recommendation Guide, Publication No. 41, 196 pp., Bangladesh Agricultural Research Council, Dhaka, Bangladesh.

Barthelmes, D., Bramick, U. 2003. Variability of a cyprinid lake ecosystem with special emphasis on the native fish fauna under intensive fisheries management including common carp (Cyprinus carpio) and silver carp (Hypophthalmichthys molitrix). Limnologica, 72: 331-342.

Beitinger, T.L., Fitzpatric, L.C. 1979. Physiological and ecological correlates of preferred temperature in fish. American Zoologist, 19: 319-329.

Brezonic, P.L., Crisman, T.L., Schluze, R.L. 1984. Planktonic communities in Florida (USA) softwater lakes of varying $\mathrm{pH}$. Canadian Journal of Fisheries and Aquatic Sciences, 41: 46-56.

Chiba, K. 1971. Studies on the carp culture in running water pond. (iii) On the relation between fish growth or harvest and environmental conditions in fish ponds. Bulletin of Freshwater Fisheries Research Laboratory Tokyo, 20: 111-215.

Dhawan, A., Kaur, S. 2002. Pig dung as pond manure. Effect on water quality, pond productivity and growth of carps in poly-culture system. Naga: The ICLARM Quarterly, 25: 11-14.

Garg, S.K., Bhatnagar, A. 1999. Effect of different doses of organic fertilizer (cowdug) on pond productivity and fish biomass in still water ponds. Journal of Applied Ichthyology, 15: 10-18.
Goolish, E.M., Adelman, I.R. 1984. Effect of ration size and temperature on the growth of juvenile common carp (Cyprinus carpio L.). Aquaculture, 36: 27-35.

Hawkins, P.R., Griffiths, D.J. 1986. Light attenuation in a small tropical reservoir (Solomon Dam, North Queensland): Seasonal changes and effect of artificial aeration. Australian Journal of Marine and Freshwater Research, 37: 199-208.

Javed, M., Hassan, M., Sial, M.B. 1992. Fish pond fertilization. IV. Effect of cowdung on the growth performance of major carps. Pakistan Journal of Agricultural Sciences, 29: 111-115.

Javed, M., Sial, M.B. 1991. Fish pond fertilization (iii) Effect of layer manure fertilization on the growth performance of fish viz., Catla catla, Labeo rohita and Cirrihinus mrigala. Pakistan Journal of Agricultural Sciences, 28: 115-120.

Javed, M. 1988. Growth Performance and Meat Quality of Major Carps as Influenced by Pond Fertilization and Feed Supplementation. Ph.D. Thesis, 281 pp., University of Agriculture, Faisalabad, Pakistan.

Jhingran, V.G., Pullin, R.S.V. 1985. A hatchery manual for the common, Chinese and Indian major carp. ICLARM Studies and Reviews 11, 191 pp., Asian Development Bank, Manila, Phillipines and International Center for Living Aquatic Resources Management, Manila, Phillipines.

Jhingran, V.G. 1982. Fish and Fisheries of India, 666 pp., $2^{\text {nd }}$ revised edition, Hindustan Publishing Corporation, New Delhi, India.

Kang'ombe, J., Brown, J.A., Halfyard, L.C. 2006. Effect of using different types of organic animal manure on plankton abundance and on growth and survival of Tilapia rendalli (Boulenger) in ponds. Aquaculture Research, 37: 1360-1371.

Knud-Hansen, C.F., McNabb, C.D., Batterson, T.R. 1991. Application of limnology for efficient nutrient utilization in tropical pond aquaculture. Verhandlungen der Internationalen Vereinigung fur Theoretische und Angewandte Limnologie, 24: 2541-2543.

Machado, C.R., Costagnolli, N. 1976. Preliminary observation related to the culture of Rhamdia hilarii, a Brazillian cat fish. FAO Technical Conference on Aquaculture, Kyoto, Japan $26^{\text {th }}$ May, 1976, Fishery Resources and Environment Division, 12 pp., FAO, Rome, Italy. 
Mahboob, S., Sheri, A.N. 1993. Regression studies on the physicochemical characteristics and planktonic life of fishpond. Pakistan Journal of Zoology, 25: 19-21.

Milstein, A., Wahab, M.A., Rahman, M.M. 2002. Envoirnmental effect of common carp Cyprinus carpio (L.) and mrigal. Cirrhinus mrigala (Hamilton) as bottom feeders in major Indian carp polyculture. Aquaculture Research, 33: 1103-1117.

Natarajan, M., Varghese, T.J. 1980. Studies on the effects of poultry manure, digested sewage study cake and cowdung on the growth of Catla catla (Hamilton) and Cyprinus carpio var. Communis (Linneaus). Agricultural Waste, 2: 261-271.

Nazneen, S. 1980. Influence of hydrological factors on the seasonal abundance of phytoplankton in Kinjhar Lake, Pakistan. Hydrobiologia, 65: 262282.

Parveen, N. 1986. Study on the Relationship Between Physicochemical and Biological Aspects of Fisheries and Storage Water Tank. M. Phil. Thesis, 56 pp., University of Agriculture, Faisalabad, Pakistan.

Rappaport, V., Sarig, S. 1978. The results of manuring on intensive growth fish farming at the Ginosar Station ponds. Bamidgeh, 29: 57-70.

Sharma, B.K., Kumar, D., Das, S.R., Chakraborty, D.P. 1979. Observations on swine dung recycling in composite fish culture. In: Proceedings of Symposium on Inland Aquaculture (Abstract), Central Inland Capture Fisheries Research Institute, Barrackpore, India.

Sheri, A.N., Sial, M.B., Javed, M. 1986. Nutrient requirements of the fish. I. Pond fertilization with N.P.K. (20:20:5). Pakistan Journal of Agricultural Sciences, 23: 266-277.

Singh, C.G. 1964. Seasonal fluctuations in diatoms populations. Tropical Ecology, 5: 42-51.

Vasisht, H.S., Jindal, R. 1980. Rheological survey of a Pucka stream of Patiala (Punjab, India). Limnologica, 12: 77-83.

Wahab, M.A, Rahman, M.M., Milstein, A. 2002. The effect of common carp, Cyprinus carpio (L) and mrigal, Cirrhinus mrigala (Hamilton) as bottom feeders in Major Indian carp polycultures. Aquaculture Research, 33: 547-556.

Welch, P.S. 1952. Limnological Methods, 538 pp., Mc Graw Hill Book Co. Inc., New York, USA. 